\title{
Impact of climate change on climatic zoning of common bean in the South of Brazil
}

\author{
Angelo Mendes Massignam ${ }^{1(*)}$, Cristina Pandolfo ${ }^{1}$, Anderson Santi ${ }^{2}$, Paulo Henrique Caramori ${ }^{3}$ and Matheus Boni Vicari ${ }^{4}$ \\ ${ }^{1}$ Empresa de Pesquisa Agropecuária e Extensão Rural de Santa Catarina - Epagri/CIRAM, Rodovia Admara Gonzaga, 1347, Itacorubi - Caixa Postal 502, \\ CEP 88034-901 Florianópolis, SC, Brazil. E-mails: cristina@epagri.sc.gov.br and massigna@epagri.sc.gov.br \\ ${ }^{2}$ Embrapa Trigo, Rodovia BR 285, km 294, Caixa Postal 3081, CEP 99050-970 Passo Fundo, RS, Brazil. E-mail: anderson.santi@embrapa.br \\ ${ }^{3}$ Instituto Agronômico do Paraná, Rodovia Celso Garcia Cid, 375 - Conjunto Ernani Moura Lima II, CEP 86047-902 Londrina, PR, Brazil. \\ E-mail: pcaramori@gmail.com \\ ${ }^{4}$ University College London, Gower St, Bloomsbury, London WC1E 6BT, E-mail: matheus.boni.vicari@gmail.com \\ ${ }^{(*)}$ Corresponding author
}

\section{ARTICLE INFO}

Article history:

Received 14 March 2017

Accepted 27 December 2017

Index terms:

Phaseolus vulgaris L.

temperature

PRECIS

sowing time
ABSTRACT

The common bean (Phaseolus vulgaris L.) is a crop of high economic and social importance in Brazil. The objective of this study is to determine the impacts of climate change on climatic zoning, i.e., to define aptitude classes for cultivation and the periods recommended for the sowing times of the common bean in rainfed conditions for the period 2071 to 2100 in the states of Paraná, Santa Catarina and Rio Grande do Sul, in the south of Brazil. Three climate scenarios were used to evaluate the potential impact of climate change on climatic zoning of the common bean crop: current (baseline - 1961-1990) and predicted future climatic conditions (2071-2100) (A2 and B2). The climatic zoning for the three scenarios (current, A2 and B2) were elaborated with the following aptitude classes: suitable and unsuitable for crop cultivation. Suitable for cultivation of common bean crop was considered when at least one 10 day period was indicated for sowing time. In the south of Brazil there is a spatial and temporal change of area suitable for cultivation and recommended sowing time by climatic zoning for the common bean crop in the future scenarios, both optimistic (B2) and pessimistic (A2).

This study was supported by grants from FINEP (Agency for the Financing of Studies and Projects)

C 2017 SBAgro. All rights reserved.

\section{Introduction}

In Brazil, the common bean (Phaseolus vulgaris L.) is a crop of great economic and social importance. The common bean is one of the grain crops that have a prominent position in terms of area, volume produced and economic value of production. The common bean has an important role as a source of vegetable protein. In addition, bean is one of the major components of the national basic food basket. 
Common bean is a crop with short cycle and, therefore, more sensitive to changes in climatic conditions (Hoffmann Júnior et al., 2007). In general, rainfall, air temperature and solar radiation are the climatic factors that influence its grain yield (Didonet \& Silva, 2004; Didonet, 2010). Common bean presents low drought tolerance due to anatomical and physiological limitations as well as low resilience to water deficit conditions (Fancelli \& Dourado Neto, 1991). The commercial production of beans occurs when air temperature ranges between 19 to $22{ }^{\circ} \mathrm{C}$, with maximum and minimum air temperatures no greater and no lower than $30.0^{\circ} \mathrm{C}$ and $8.3^{\circ} \mathrm{C}$, respectively (Garcia, 1969). Higher air temperatures during the flowering period reduce its production and pollen viability, number of pods per plant, number of seeds per pod, and grain mass, all of which negatively affect grain yield (Prasad et al., 2002; Massignam et al., 1998a).

Recent global studies have shown consistent changes in rainfall (Zhang et al., 2007) and air temperature in various parts of the globe (IPCC, 2007). In Brazil, some studies have estimated the impact of climate change on the culture of the common bean. The study of the impact of rising air temperatures on climatic zoning of common bean in the state of Mato Grosso do Sul showed that the reduction of crop yield will be more pronounced in areas with soils with less water storage capacity and with greater increase in air temperature (Silva et al., 2012). In the states of Goiás and Minas Gerais, the study of economic impacts of climate change on common bean showed a significant reduction of areas suitable for planting, and it can promote a strong impact on the economy of those states (Martins \& Assad, 2007).

In Paraná, in Santa Catarina, and in Rio Grande do Sul studies (Camargo, et al., 2006, Marengo \& Camargo, 2008; Minuzzi, 2010; Minuzzi et al., 2011) have also pointed to an impact on air temperature and rainfall. In general, these studies indicate an increase in the air temperature, especially in minimum air temperatures, and an evidence of the increase in the intensity of rainfall events. The impacts of climate change on bean production in Central America for 2050 can be considered drastic, with estimated reductions of up to $25 \%$ of the total volume of production (Schmidt et al., 2012). In Santa Catarina, the study of the impacts caused by the homogeneous and linear increase of $2^{\circ} \mathrm{C}$ in the next 50 years in maximum, average and minimum air temperature, and keeping the same rainfall values, showed that this increase will impact significantly the productive chain of the common bean (Pandolfo et al., 2007).

The HadRM3P climate model was used in many studies as a tool to generate the climate data for many studies of impact of climate change. According to Marengo et al. (2009), the HadRM3P regional model has a good representation of the current climate in South America. However, a more detailed study showed that the annual rainfall in the south of Brazil is slightly overrated by the regional model HadRM3P, especially in spring and summer. During winter months, there is no significant difference between the observed data and simulated data by the regional model for the Rio Grande do Sul and Santa Catarina states (Camargo et al., 2011). Air temperatures simulated by the regional model for the south of Brazil showed good agreement with the observed data (Camargo, 2010).

The objective of this study is to determine the impacts of climate change on climatic zoning, i.e., to define aptitude classes for cultivation and to define the increase, maintenance and decrease of the periods indicated for the sowing times of the common bean in rainfed conditions for the period 2071 to 2100, in the states of Paraná, Santa Catarina and Rio Grande do Sul, in the south of Brazil.

\section{Material and methods}

The states of Paraná, Santa Catarina and Rio Grande do Sul are located in the south of Brazil, between the

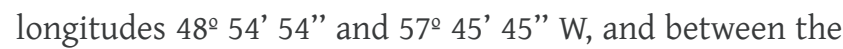
latitudes $23^{\circ} 02^{\prime} 12^{\prime \prime}$ and $33^{\circ} 19^{\prime} 18^{\prime \prime} \mathrm{S}$. The total area of the three states is $576,774.3 \mathrm{~km}^{2}$, representing $6.77 \%$ of the area of the national territory. According to the Köppen climate classification, there are three climate types: Cfa, $\mathrm{Cfb}$ and Af (Wrege et al., 2011). The state of Rio Grande do Sul is composed of 496 municipalities, the Paraná has 399 municipalities and the state of Santa Catarina has 295 municipalities.

Three climate scenarios were used to evaluate the potential impact of climate change on climatic zoning of the common bean crop in the south of Brazil: current (baseline1961-1990) and predicted future climatic conditions (20712100) based on IPCC Scenarios, described as pessimistic (A2) and optimistic (B2). The climate model HadRM3P was used as a tool to generate the daily data of rainfall and maximum, average and minimum air temperature for the three climate scenarios like the methodology employed by Marengo et al. (2009). This model is part of the Integrated Regional Modeling PRECIS (Providing Regional Climate for Impacts Studies). This model has a horizontal resolution of $50 \mathrm{~km}$, with 19 levels in the vertical direction (from the surface up to $30 \mathrm{~km}$ in the stratosphere) and 4 levels in the soil. Nakicenovic et al. (2013) describe scenario A2 with high population growth, medium GDP growth, high energy consumption, medium to high change in land use, low availability of resources, slow technological development, and regional energy. Scenario B2 presents medium population growth, GDP growth medium, medium energy consumption change, medium change in land use, 
medium availability of resources, medium technological development, and energy dynamics like usual.

The daily data on total rainfall and on maximum, average and minimum air temperature for the three scenarios (current, A2 and B2) were obtained from the PRECIS model in the scale of $0.5 \times 0.5$ degrees $(50 \mathrm{~km} \times 50$ $\mathrm{km}$ horizontal resolution $\sim 10 \mathrm{~km} \times 10 \mathrm{~km}$ ). Total monthly rainfall was interpolated by ordinary kriging and extracted to grid of $900 \mathrm{~m} \times 900 \mathrm{~m}$, with the software ArcGis version 9,3 and 10. These geo-referenced elevation grid points in a mesh with regularly spaced points $90 \mathrm{~m}$ were obtained from the relief map for the south of Brazil made available by Miranda (2010) on the scale of 1:250,000. An analysis of consistency was made to eliminate the noises (missing data with zero points). The resulting grid presented more than 760,000 points, covering Rio Grande do Sul, Santa Catarina and Paraná.

The maximum, average and minimum air temperatures were estimated to grid of $900 \mathrm{~m} \times 900 \mathrm{~m}$ by equations of regression. A total of 108 equations (three climatic variables, three scenario and twelve months) were adjusted using multiple linear regression between the maximum, average and minimum air temperatures (dependent variables) and the latitude, longitude and altitude (independent variables) to the South of Brazil.

The climatological water balance used for the three scenarios (current, A2 and B2) was developed by Thornthwaite Mather (Thornthwaite and Mather, 1955). It was assumed that the available water capacity was the same for the three states and its value was $100 \mathrm{~mm}$. The potential evapotranspiration has been calculated by the Thornthwaite method. The climatological water balance was calculated using the total monthly rainfall and average monthly air temperature were obtained from the PRECIS model in the scale of $0.5 \times 0.5$ degrees $(\sim 10 \mathrm{~km} \times 10 \mathrm{~km})$.

The criterion used to estimate water availability was the water requirement satisfaction index (WRSI). The WRSI is defined as the ratio between the actual evapotranspiration and the potential evapotranspiration. The monthly WRSI values were interpolated by the method of the inverse square of the distance and they were extracted to the grid of ZonExpert using the software ArcGis version 9,3 and 10.

The methodology of climatic zoning was based on climatic risk zoning for the bean crop of the Brazilian Ministry of Agriculture, Livestock, and Food Supply (Brasil, 2013a; Brasil, 2013b; Brasil, 2013c). ZonExpert 1.0 (Pandolfo et al., 1999) is software that has been used to define climatic zoning for all agricultural crops in the Santa Catarina state and it was used in this work for climatic zoning of common bean. The climatic zoning for the three scenarios (current, A2 and B2) was elaborated with the following aptitude classes: suitable and unsuitable for crop cultivation. Suitable for cultivation of common bean crop was considered when at least one 10 day period was indicated for sowing time.

The number of grid points $(760,000)$ was reduced due to the excessive processing time for ZonExpert 1.0 software. A subgrid was generated through a sampling technique of each municipality. The criterion sampling was used to randomly select a point georeferenced within a predefined range for every $100 \mathrm{~m}$ for all municipalities. This subgrid resulted in 6,341points and each point represented a percentage of the area in relation to the total area of the municipality.

The possibility of sowing the common bean was tested for each point of the subgrid georeferenced by the software in 3610 day periods by ZonExpert. The criteria to indicated sowing time by climatic zoning of common bean were when: the maximum monthly air temperature was lower than $30^{\circ} \mathrm{C}$ from the fourth 10 day period after sowing to the end of the crop cycle, the minimum monthly air temperature was higher than or equal to $11^{\circ} \mathrm{C}$ throughout the crop cycle, and the monthly (WRSI) was higher than or equal to 0.65 throughout the crop cycle. In the municipality sowing time was indicated for 10 day period when at least $20 \%$ of the area represented by points of the subgrid were considered indicated.

The crop cycles of common bean cultivars vary depending on sowing time and place. A cycle of 90 days was considered to represent the crop cycle of common bean cultivars indicated for the three states.

The increase, maintenance and decrease of the indicated sowing time period were calculated by comparing the number of 10 day periods with the indicated sowing time between the current scenario and future scenarios (A2 and B2).

\section{Results and Discussion}

In climatic zoning of the common bean for the current scenario, all municipalities in the states of Paraná, Santa Catarina and Rio Grande do Sul had area suitable for crop cultivation, except two municipalities in the North of Paraná. The climatic zoning of the common bean for the future scenarios A2 and B2 showed an increase in the number of municipalities with areas unsuitable for crop cultivation (28 and 27, respectively). These municipalities were concentrated in the North of Paraná. This spatial change of climatic zoning in Paraná represented a reduction of the area suitable for common bean cultivation by $3.9 \%$ and $3.8 \%$ for the future scenarios A2 and B2, respectively (Figure 1). In contrast, Pandolfo et al. (2007) using different methodology and period concluded that some municipalities of Santa Catarina were considered unsuitable for common bean cultivation. This study assumed a linear increase of $2^{\circ} \mathrm{C}$ 
Figure 1. Climatic zoning for the common bean in the current (a), A2 (b) and B2 (c) scenarios in the states of Paraná, Santa Catarina and Rio Grande do Sul, Brazil. (a)

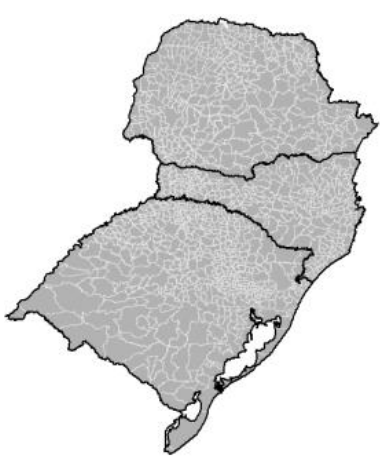

(b)

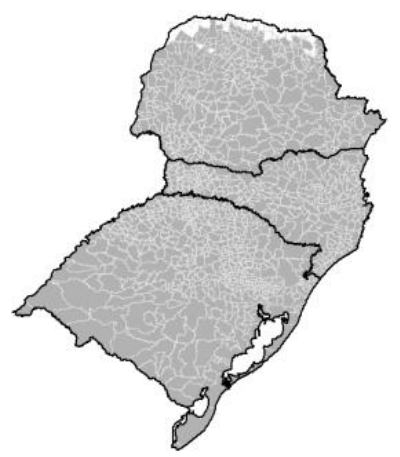

(c)

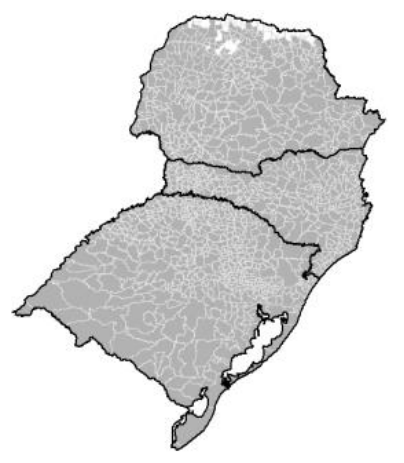

Figure 2. Difference in the number of 10 day periods between the period of sowing time indicated for the current scenario and scenarios "A2" (a) and "B2" (b) of the climatic zoning of the common bean in the states of $\mathrm{Pa}-$ raná, Santa Catarina and Rio Grande do Sul, Brazil. (a)

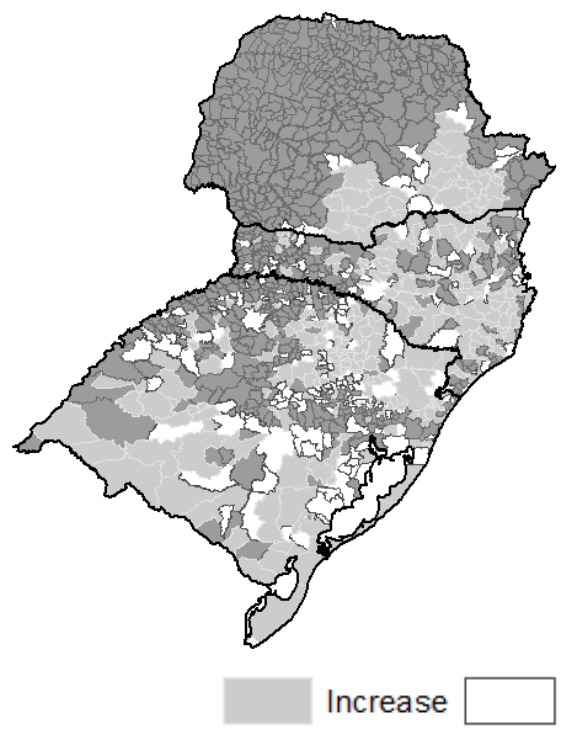

(b)

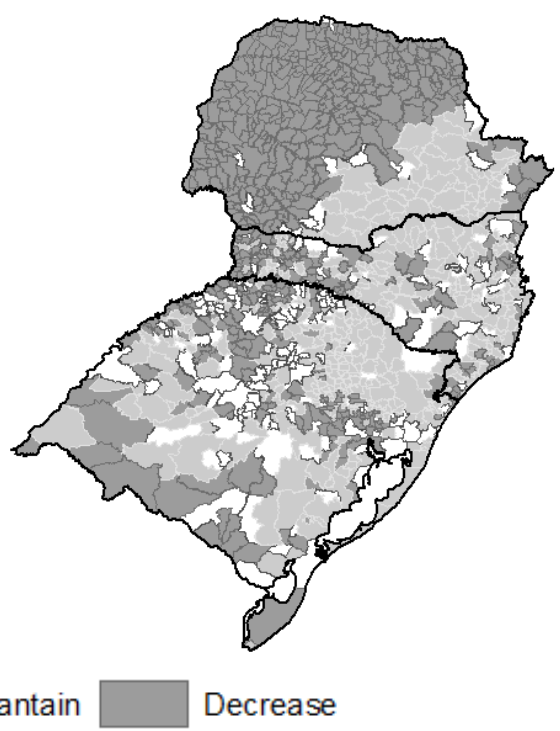

in the maximum, average and minimum air temperature over the next 50 years (2007-2057) and no change in the total rainfall. This restriction of cultivation was due to an increase in maximum air temperatures and in water deficit. The increased water deficit resulted from the increasing potential evapotranspiration with the same amount of total rainfall. In contrast, the model HadRM3P pointed to an increase in seasonal and annual rainfall in the south of Brazil (Camargo et al., 2011) and this increase of rainfall compensated for the increase of potential evapotranspiration.

In the future scenarios, the indicated sowing period was reduced primarily due to an increase in maximum air temperatures and water deficit in municipalities where these variables were already high in the current scenario (Figure 2). High air temperatures at flowering period combined with water deficit are the main cause of the reduction in grain yield of common bean (Massignam et al., 1998). On the other hand, the increase of air temperature in future scenarios increased the period of indicated sowing time in municipalities which had low air temperatures in the current scenarios. This is due to the decrease of frost risk.

Overall, the response of the climate change impacts projected for future scenarios A2 and B2 were different in the three states (Table 1 and Figure 3). The indicated sowing time period by climatic zoning for the common bean in the future scenarios (A2 and B2) reduced significantly in Paraná state. In the state of Rio Grande do Sul there was a small increase of the indicated sowing time period for both futures scenarios. In Santa Catarina, there was a small reduction in the indicated sowing time period for future scenario A2 and a small increased indicated sowing time period for future scenario B2. In all three states there was a significantly temporal change of the indicated sowing time period by climatic zoning for both future scenarios in relation to the current scenario.

There was a difference in response of the climatological variables in determining the sowing times among the states. In the states of Rio Grande do Sul and Santa Catarina the minimum air temperature was the most important climatic variable for determining the indicated sowing 
Figure 3. Average number of municipalities with sowing time indicated for common bean as function of 10 day period for the three scenarios in Paraná (a), Santa Catarina (b) and Rio Grande do Sul State, Brazil (c).
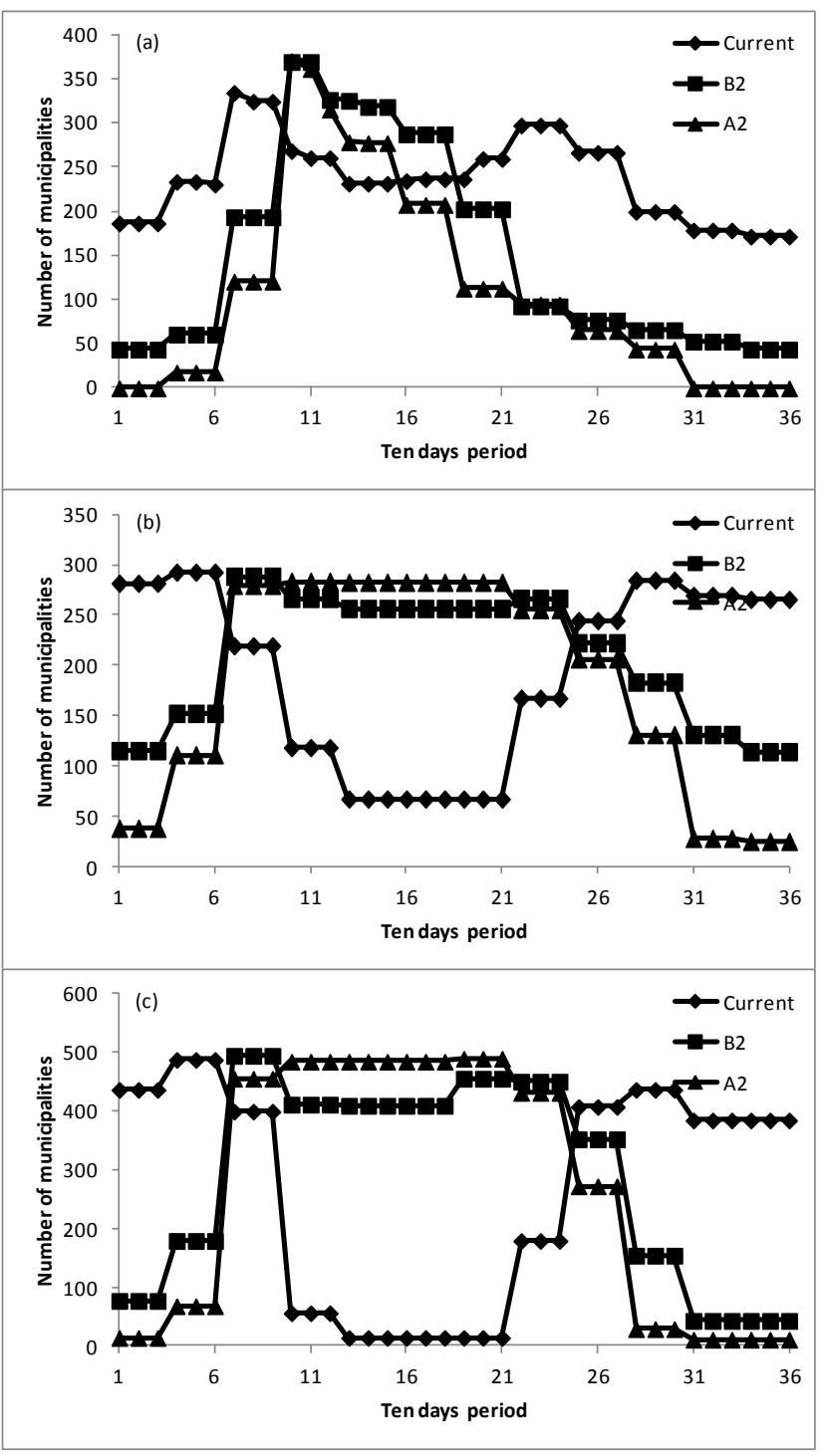

time period for common bean in the current scenario. In future scenarios, the maximum air temperature became the most important climatic variable for determining the indicated sowing time period for common bean. The water deficit did not restrict the indicated sowing time period for the current and future scenarios for these two states (Table 2). In the state of Paraná the maximum and minimum air temperatures were the most important climatic variables to determine the indicated sowing time period for the culture of the common bean in the current scenario. In future scenarios the maximum air temperature became the most important climatological variable following the WRSI for determining the indicated sowing time period (Table 2). These differences of the impacts of climate change among the three states could be explained because both future scenarios of HadRM3P model showed a different spatial distribution of the increase in air temperature
Table 1. Average number of 10 day periods with sowing time indicated for the common bean crop in the current scenario and future scenarios A2 and B2 for the state of Paraná, Santa Catarina and Rio Grande do Sul, Brazil.

\begin{tabular}{lccc}
\multirow{2}{*}{ State } & \multicolumn{3}{c}{ Number of $\mathbf{1 0}$ day periods } \\
& Current & B2 & A2 \\
\hline Paraná & 21.4 & 13.5 & 9.7 \\
\hline Santa Catarina & 24.0 & 25.6 & 22.5 \\
\hline Rio Grande do Sul & 19.4 & 21.0 & 19.5 \\
\hline
\end{tabular}

Table 2. Average number of 10 day periods with sowing time not indicated per climatic variable for the common bean in Paraná (PR), Rio Grande do Sul (RS) and Santa Catarina (SC), the South of Brazil.

\begin{tabular}{llrrr}
\hline \multirow{2}{*}{ State } & Climatological & \multicolumn{3}{c}{ Scenario } \\
& variable & Current & \multicolumn{1}{c}{ A2 } & \multicolumn{1}{c}{ B2 } \\
\hline PR & WRSI & 1.2 & 2.4 & 3.9 \\
PR & Maximum air temperature & 7.7 & 19.7 & 23.2 \\
PR & Minimum air temperature & 7.8 & 1.3 & 0.5 \\
\hline RS & Maximum air temperature & 2.0 & 12.8 & 15.9 \\
RS & Minimum air temperature & 16.4 & 4.2 & 1.6 \\
SC & Maximum air temperature & 0.8 & 8.1 & 11.7 \\
SC & Minimum air temperature & 15.9 & 5.1 & 3.0 \\
\hline
\end{tabular}

in the south of Brazil. Paraná state shown higher air temperature anomalies whereas, in the south and south coast of Rio Grande do Sul showed the smaller anomalies (Camargo, 2010).

A study of the effect of high air temperatures on crop yield of common bean concluded that the highest grain yields were obtained in the range of maximum air temperatures between 24 and $27{ }^{\circ} \mathrm{C}$ (Massignam et al., 1998). However, there is considerable increased variability and decreased grain yield when the maximum air temperatures were above $28^{\circ} \mathrm{C}$. Maximum air temperatures in many municipalities are already relatively high. Approximately $63 \%$ of municipalities in the three states had maximum air temperatures above $27{ }^{\circ} \mathrm{C}$ during the indicated sowing time period in the current scenario. This shows that a small increase in air temperature could have a significant impact on the grain production of common bean. In addition, in Paraná, the increase in maximum air temperatures was associated with increased water deficit in the future scenarios (A2 and B2) (Table 2). According to Massignam et al. (1998), higher air temperatures and water deficit during the flowering period are the main causes of the reduction in grain yield of common bean. These results suggest that the grain production of common bean in the south of Brazil tends to decrease as a result of the impact of rising air temperatures and water deficit in the future scenarios. However, a simulation study of the impacts of climate change on the common bean with simulation 
Figure 4. Average daily solar radiation per month for Southern Brazil and the low limit of the optimal solar radiation (13 $\mathrm{MJ} \mathrm{m}^{-2}$ day $^{-1}$ ) for the common bean (Didonet \& Silva, 2004). Source: Campos Novos, SC: from Epagri/Ciram; Foz do Iguaçu, PR and Porto Alegre, RS: from INMET; São Paulo, SP: from Pereira et al. (2007).

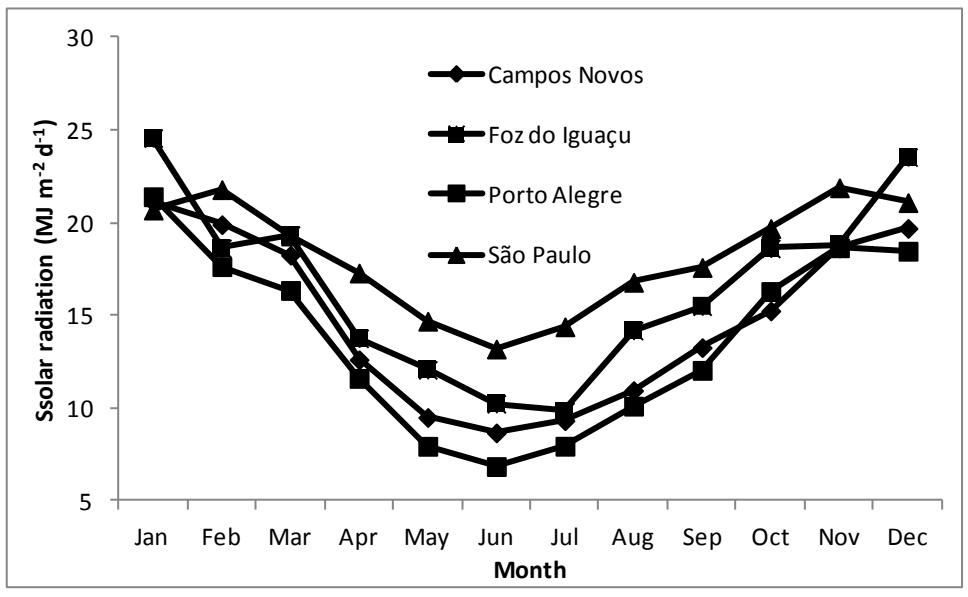

models concluded that productivity will increase in different regions of the state of Minas Gerais, Brazil. This significant increase in productivity is due to the beneficial effects of $\mathrm{CO}_{2}$ for beans (Silva Júnior et al., 2007). In contrast, Costa et al. (2009), in a study of the impacts of climate change, increasing $\mathrm{CO}_{2}$ and technological trend of the bean on the state of Minas Gerais, concluded that the potential productivity between the years 2050 and 2080 will reduce by $30 \%$. This reduction in productivity is primarily associated with the reduction of the crop cycle period. These results are in agreement with other studies (Prasad et al., 2002; Jifon \& Wolfe, 2005), which concluded that the increase in $\mathrm{CO}_{2}$ would not compensate for the negative effects of high air temperatures during the reproductive phase.

In general, the climatic factors that influence the grain yield of common bean are air temperature, solar radiation and rainfall (Didonet \& Silva, 2004; Didonet, 2010). However, the climatic zoning published by several studies (Massignam et al., 1998b; Caramori et al., 2001; Maluf et al., 2001) and the Ministry of Agriculture, Livestock and Food Supply (Brasil, 2013a; Brasil, 2013b; Brasil, 2013c) for the south of Brazil states did not use solar radiation as a climatic variable to establish aptitude classes for climatic zoning. Solar radiation significantly influences the photosynthesis rate and, consequently, also influences the crop yield. Therefore, the common bean crop should be managed to intercept the highest possible amount of solar radiation, mainly in the vegetative stage. This strategy aims to maximize biomass production as well as the number of pods per plant (Didonet \& Silva, 2004). The amount of solar radiation necessary for maximum photosynthetic rate varies with age and crop. In general, solar radiation from 13 to $22 \mathrm{MJ} \mathrm{m}^{-2} \mathrm{day}^{-1}$ is considered optimal for the common bean. The photosynthetic rate remained practically constant when solar radiation was above $35 \mathrm{MJ} \mathrm{m}^{-2}$ day $^{-1}$ (Didonet \& Silva, 2004). In the current scenario, solar radiation was greater than $13 \mathrm{MJ} \mathrm{m}^{-2}$ day${ }^{1}$ during the indicated sowing times for common bean in the states of South Brazil. However, the period of crop development could coincide with periods of lower solar radiation (Figure 4) in the future scenarios (Figure 3). It was due to the strong change of indicated sowing time period for common bean. Therefore, future studies should consider the effect of solar radiation to establish aptitude classes for climatic zoning and to establish the indicated sowing time for the common bean crop.

Other effects of climate change impacts in the production of the common bean could be the indirect effect of diseases, pests and weeds and these factors should also be studied. Climate change may cause changes in both the spatial and the temporal distribution of the disease and, consequently, control methods must adapt to this new fact (Ghini et al., 2008). Considering the future climate scenarios for increasing the air temperature, it may be concluded that there will be an increase in the degree of importance of fusarium wilt, caused by Fusarium oxysporum f. sp. tracheiphilum (Smith) Snyder \& Hansen. The growth and sporulation of this pathogen increase with higher air temperatures (Pinheiro et al., 2012).

\section{Conclusion}

In the south of Brazil there is a spatial and temporal change of area suitable for cultivation and indicated sowing time by climatic zoning for the common bean crop in the future scenarios, both optimistic (B2) and pessimistic (A2).

In the states of Santa Catarina and Rio Grande do Sul, the minimum air temperature is the main climatic variable that determines the indicated sowing time for the current scenario. In contrast, the maximum air temperature becomes the main climatic variable that determines the indicated sowing time for the future scenarios.

In the state of Paraná, the minimum and maximum air 
temperatures are the main variables that determine the indicated sowing time for the current scenario, whereas maximum air temperature and water deficit become the main climatic variable which restrain the indicate sowing time for common bean for the future scenarios.

\section{References}

BRASIL. Portaria nº 33 de 11 de julho de 2013. Zoneamento Agrícola de Risco Climático para a cultura de feijão $1^{\mathfrak{a}}$ safra no Estado do Paraná, ano-safra 2013/2014. Ministério da Agricultura e do Abastecimento. Secretaria de Política Agrícola. Diário Oficial da União, Brasília, DF, 11 julho. 2013a.

BRASIL. Portaria nº 35 de 11 de julho de 2013. Zoneamento Agrícola de Risco Climático para a cultura de feijão $1^{\mathrm{a}}$ safra no Estado do Rio Grande do Sul, ano-safra 2013/2014. Ministério da Agricultura e do Abastecimento. Secretaria de Política Agrícola. Diário Oficial da União, Brasília, DF, 11 julho. 2013 b.

BRASIL. Portaria nº 36 de 11 de julho de 2013. Zoneamento Agrícola de Risco Climático para a cultura de feijão $1^{\mathrm{a}}$ safra no Estado de Santa Catarina, ano-safra 2013/2014. Ministério da Agricultura e do Abastecimento. Secretaria de Política Agrícola. Diário Oficial da União, Brasília, DF, 11 julho. 2013c.

CAMARGO, C.G.; MALANDRIN, D.A.; MARENGO, J.; BRAGA, H.J.; PANDOLFO, C.; MASSIGNAM, A.M. Análises dos padrões climáticos futuros de precipitação na região Sul do Brasil. In: CONGRESSO BRASILEIRO DE AGROMETEOROLOGIA, 17, 2011, Guarapari, Es. Anais.... Guarapari, ES: Incaper, 2011.

CAMARGO, C. G. Padrões climaticos atuais e futuros de temperatura do ar na regiao sul do Brasil e seus impactos nos cultivos de pêssego e de nectarina em Santa Catarina, 2010. Thesis (Doctoral dissertation in Meteorology) - Instituto Nacional de Pesquisas Espaciais, São José dos Campos.

CAMARGO, C.G.C.; BRAGA, H.J.; ALVES, R. Mudanças Climáticas Atuais e Seus Impactos no Estado de Santa Catarina. Agropecuária Catarinense, Florianópolis, v.19, n.3, p. 31-35, Nov. 2006.

CARAMORI, P.H.; GONÇALVES, S.L.; WREGE, M.S.; et al. Zoneamento de riscos climáticos e definição de datas de semeadura para o feijão no Paraná. Revista Brasileira de Agrometeorologia, Passo Fundo, v. 9, n.3. 477-485, 2001.

COSTA, L.C.; JUSTINO, F.; OLIVEIRA, L.J.C.; SEDIYAMA, G.C.; FERREIRA, W.P.M.; LEMO, C.F. Potential forcing of $\mathrm{CO}_{2}$, technology and climate changes in maize (Zea mays) and bean (Phaseolus vulgaris) yield in southeast Brazil. Environmental Research Letters, v. 4, n. 1, p.1-10, 2009.

DIDONET, A. D. Importância do período pré-floração na produtividade do feijoeiro. Pesquisa Agropecuária Tropical, Goiânia, v. 40, p. 505-512, 2010.

DIDONET, A. D. \& SILVA, S. C. Elementos climáticos e a produtividade do feijoeiro. Informe Agropecuário, Belo Horizonte, v. 25, n. 223, p. 13-19, 2004

FANCELLI, A.L., DOURADO NETO, D. Feijão irrigado. 2. ed, Piracicaba: ESALQ/USP, 1991. 266 p.

GARCIA, J.B. Zonificacion de Phaseolus vulgaris en funcion de su regimen hídrico. Agronomia Tropical, v. 19, n. 3, p. 197-203, 1969.

GHINI, R.; HAMADA, E.; BETTIOL, W. Climate change and plant diseases. Scientia Agricola, Piracicaba, v. 65, special issue, p.98-107, 2008.

HOFFMANN JÚNIOR, L., RIBEIRO, N. D., ROSA, S. S. DA, JOST, E., POERSCH, N. L., ; MEDEIROS, S. L. P. Resposta de cultivares de feijão à alta temperatura do ar no período reprodutivo. Ciência Rural, Santa Maria, v. 37, n. 6, p. 1543-1548, 2007.

IPCC. Climate Change 2007: the physical science basis. Summary for Policymakers. Contribution of Working Group I to the Fourth Assessment Report of the Intergovernmental Panel on Climate Change. Paris, 21 p., 2007.
JIFON, J. L. \& WOLFE, D. W. High temperature-induced sink limitation alters growth and photosynthetic acclimation to elevated $\mathrm{CO}_{2}$ in bean (Phaseolus vulgaris L.). Journal of the American Society for Horticultural Science, v. 130, n. 4, p. 515-520, 2005.

MALUF, J. R. T.; CUNHA, G. R.; MATZENAUER, R.; PASINATO, A.; PIMENTEL, M. B. M.; CAIAFFO, M. R. Zoneamento de riscos climáticos para a cultura de feijão no Rio Grande do Sul. Revista Brasileira de Agrometeorologia, Passo Fundo, v. 9, p. 468-476, 2001.

MARENGO, J. A. \& CAMARGO, C. C. Surface air temperature trends in Southern Brazil for 1960-2002, International Journal of Climatology, v. 28, p. 893-904, 2008.

MARENGO, J. A.; AMBRIZZI, T. ; ROCHA, R. P. ; ALVES, L.M. ; CUADRA, S. V.; VALVERDE, M.C. ; TORRES, R.R. ; SANTOS, D.C. ; FERRAZ, S. E. T. Future change of climate in South America in the late twenty-first century: intercomparison of scenarios from three regional climate models. Climate Dynamics, v. 35, n. 6, p. 1073-1097, 2009.

MARTINS, N. P. \& ASSAD. E. D. Impactos econômicos das possíveis alterações climáticas na cultura do feijão nos estados de Goiás e Minas Gerais. In: CONGRESSO BRASILEIRO DE AGROMETEOROLOGIA, 15, Aracajú, SE. 02 a 05 de julho de 2007. Anais... Aracaju, SE: SBA; Embrapa Tabuleiros Costeiros, 2007. CR-ROM.

MASSIGNAM, A. M.; VIEIRA, H. J.; HEMP.; FLESCH, R. D. Ecofisiologia do feijoeiro. II - Redução do rendimento pela ocorrência de altas temperaturas no florescimento. Revista Brasileira de Agrometeorologia, Santa Maria, v. 6, n. 1, p. 41-45, 1998a.

MASSIGNAM, A. M.; VIEIRA, H. J.; HEMP, S.; FLESCH, R. D. Ecofisiologia do feijoeiro. VI - Zoneamento Agroclimático para o Estado de Santa Catarina. Revista Brasileira de Agrometeorologia, Santa Maria, v. 6, n. 1, p. 69-73, 1998b.

MINUZZI, R. B. Tendências na variabilidade climática de Santa Catarina Brasil. Revista Brasileira de Engenharia Agrícola e Ambiental, Campina Grande, v.14, n.12, p.1288-1293, 2010.

MINUZZI, R. B.; CARAMORI, P. H.; BORROZINO, E. Tendências na variabilidade climática sazonal e anual das temperaturas máxima e mínima do ar no Estado do Paraná, Bragantia, Campinas, v. 70, n. 2, p. 471-479, 2011.

MIRANDA, E. E. de (Coord.). Brasil em Relevo. Campinas: Embrapa Monitoramento por Satélite, 2005. Disponível em: <http://www. relevobr.cnpm.embrapa.br>. Acesso em: 15 mar. 2010.

NAKICENOVIC, N.; ALCAMO, J.; DAVIS, G.; DE VRIES, B.; FENHANN, J.; GAFFIN, S.; GREGORY, K.; GR, A.; JUNG, T.Y.; KRAM, T.; LA ROVERE, E.L.; MICHAELIS, L.; MORI, S.; MORITA, T.; PEPPER, W.; PITCHER, H.; PRICE, L.; RIAHI, K.; ROEHRL, A.; ROGNER, H.H.; SANKOVSKI, A.; SCHLESINGER, M.; SHUKLA, P.; SMITH, S.; SWART, R.; VAN ROOIJEN, S.; VICTOR, N.; DADI, Z. Special report on emission scenarios. Intergovernmental Panel on Climate Change, 2000. Disponível em: < http://www.ipcc.ch/ ipccreports/sres/emission/index.htm >. Acesso em: 18 Jul. 2013.

PANDOLFO, C.; HAMMES, L. A.; CAMARGO, C.; MASSIGNAM, A. M.; PINTO, E. S. P.; LIMA, M. de; MILANEZ, J. M. Estimativas dos impactos das mudanças climáticas no zoneamento da cultura do feijao no estado de Santa Catarina. Agropecuária Catarinense, Florianópolis, v. 20, n.3, p. 39-42, 2007.

PANDOLFO, C.; PINTO, E. S. P.; RAMOS, A. M.; MASSIGNAM, A. M.; MIRANDA JÚNIOR, G. X.; THOME, V. M. R. Sistema computacional para elaborar o zoneamento agrícola para o Estado de Santa Catarina Zonexpert 1.0. In: CONGRESSO BRASILEIRO DE AGROMETEOROLOGIA, 11., 1999, Florianópolis, SC. Anais... Florianópolis, SC: Sociedade Brasileira de Agrometeorologia, 1999.

PEREIRA, A. R.; ANGELOCCI, L.R.; SENTELHAS, P. C. Meteorologia agrícola. Universidade de São Paulo, ESALQ: Piracicaba, SP, 192 p., 2007.

PINHEIRO, G. S.; BARBOSA, L. G.; ANGELOTTI, F.; MAGALHÃES, E. E. de; FERNANDES, H. A.; ZUCAL, M. P. M. Impacto de alterações de temperatura no crescimento e Esporulação de Fusarium oxysporum f. sp. Tracheiphilum. In: WORKSHOP SOBRE MUDANÇAS CLIMÁTICAS E PROBLEMAS FITOSSANITÁRIOS, 2012, Jaguariúna, SP. Anais... Jaguariúna: Embrapa Meio Ambiente, 2012. CD-ROM. 
PRASAD, P. V. V.; BOOTE, K. J.; ALLEN JR, L. H.; THOMAS, J. M. G. Effects of elevated temperature and carbon dioxide on seed-set and yield of kidney bean (Phaseolus vulgaris L.). Global Change Biology, v. 8, n. 8, p. 710-721, 2002.

SCHMIDT,A.; EITZINGER, A.; SONDER, K; SAIN, G. Tortillas on the roaster: central american maize-bean systems and the changing climate. Full technical report. CIAT, Catholic Relief Services and CIMMYT: 123p. 2012.

SILVA JÚNIOR, J. L. C.; COSTA, L. C.; AMORIM, M. C. DE; BARBOSA, F. J. Mudanças climáticas e agricultura: um estudo de casos para as culturas do milho e do feijão em Minas Gerais. Boletim da Sociedade Brasileira de Meteorologia, v.31, n. 1, 2007.

SILVA, S. C. da; HEINEMANN, A. B.; ASSAD, E. D.; STONE, L. F.; MORAES, A. da C. Alteração na geografia do cultivo do feijoeiro conforme aumento da temperatura do ar no Estado do Mato Grosso do Sul. In: CONGRESSO BRASILEIRO DE METEOROLOGIA, 17.; ENCONTRO DE METEOROLOGIA DOS PAÍSES DO MERCOSUL E ASSOCIADOS, 1.; ENCONTRO SUL
AMERICANO DE APLICAÇÕES DO SISTEMA EUMETCast PARA O MONITORAMENTO METEOROLÓGICO E AMBIENTAL, 4.; ENCONTRO DE METEOROLOGIA OPERACIONAL, 2., 2012, Gramado. Anais... Gramado: UFRGS, 2012. 1 CD-ROM.

THORNTHWAITE, C.W.; MATHER, J.R. 1955. The water budget and its use in irrigation, In: Water U.S. Department of Agriculture Yearbook, ed. Washington: USDA, 1955. 346-57p.

WREGE, M. S.; STEINMETZ, S.; REISSER JÚNIOR, C.; ALMEIDA, I. R. de. (Ed.). Atlas climático da Região Sul do Brasil: Estados do Paraná, Santa Catarina e Rio Grande do Sul. Pelotas: Embrapa Clima Temperado; Colombo: Embrapa Florestas, 333 p., 2011.

ZHANG, X.; ZWIERS, F. W.; HEGERL, G. C.; LAMBERT, F. H.; GILLETT, N. P.; SOLOMON, S.; STOTT, P. A.; NOZAWA, T. Detection of human influence on twentieth-century precipitation trends. Nature, v. 448, p. 461-466, 2007.

CITATION

MASSIGNAM, A. M.; PANDOLFO, C.; SANTI, A. CARAMORI, P. H.; VICARI, M. B. Impact of climate change on climatic zoning of common bean in the South of Brazil. Agrometeoros, Passo Fundo, v.25, n.2, p.313-321, 2017. 


\title{
Impacto das mudanças climáticas no zoneamento climático do feijão no Sul do Brasil
}

\author{
Angelo Mendes Massignam $\left.{ }^{1 *}\right)$, Cristina Pandolfo ${ }^{1}$, Anderson Santi ${ }^{2}$, Paulo Henrique Caramori ${ }^{3}$ e Matheus Boni Vicari ${ }^{4}$ \\ ${ }^{1}$ Empresa de Pesquisa Agropecuária e Extensão Rural de Santa Catarina - Epagri/CIRAM, Rodovia Admara Gonzaga, 1347, Itacorubi - Caixa Postal 502, \\ CEP 88034-901 Florianópolis, SC. E-mails: cristina@epagri.sc.gov.br e massigna@epagri.sc.gov.br \\ ${ }^{2}$ Embrapa Trigo, Rodovia BR 285, km 294, Caixa Postal 3081, CEP 99050-970 Passo Fundo, RS. E-mail: anderson.santi@embrapa.br \\ ${ }^{3}$ Instituto Agronômico do Paraná, Rodovia Celso Garcia Cid, 375 - Conjunto Ernani Moura Lima II, CEP 86047-902 Londrina, PR. \\ E-mail: pcaramori@gmail.com \\ ${ }^{4}$ University College London, Gower St, Bloomsbury, London WC1E 6BT, E-mail: matheus.boni.vicari@gmail.com \\ ${ }^{(*)}$ Autor para correspondência
}

\section{INFORMAÇÕES}

História do artigo:

Recebido em 14 de Março de 2017

Aceito em 27 de Dezembro de 2017

\section{Termos para indexação:}

Phaseolus vulgaris L.

temperatura

PRECIS

época de semeadura

\section{RESUMO}

O feijão comum (Phaseolus vulgaris L.) é uma cultura que tem grande importância econômica e social no Brasil. O objetivo deste estudo é determinar os impactos das mudanças climáticas no zoneamento climático da cultura do feijão, ou seja, definir as classes de aptidão para o cultivo e os períodos de épocas de semeadura indicados em condições de sequeiro para o período 2071-2100, nos Estados do Paraná, Santa Catarina e Rio Grande do Sul, Brasil. Três cenários climáticos foram utilizados para avaliar o impacto potencial das mudanças climáticas no zoneamento climático da cultura do feijão: atual 1961-1990 e as condições climáticas estimadas para o futuro (2071-2100) (A2 e B2). O zoneamento climático para os três cenários (atual, A2 e B2) foi elaborado com as seguintes classes de aptidão: cultivo apto e cultivo inapto. o cultivo apto para a cultura do feijão foi considerado quando os municípios tiveram pelo menos um decêndio com semeadura recomendada. No Sul do Brasil houve mudança espacial e temporal da área de cultivo e da época de semeadura indicada pelo zoneamento climático para a cultura do feijão nos cenários futuros, tanto no otimista (B2) como no pessimista (A2). 